\title{
Social and immunological differences among uninfected Brazilians exposed or unexposed to human immunodeficiency virus-infected partners
}

\author{
Maria Luiza Silva ${ }^{1 /+}$, Victor Hugo Melo² ${ }^{\text {Agdemir Waléria Aleixo }}$, Lúcia Fernandes Aleixo ${ }^{3}$, \\ Marcelo Antônio Pascoal-Xavier ${ }^{4}$, Rafaela Oliveira Silva ${ }^{3}$, Laís Alves Ferreira ${ }^{3}$, \\ Willian Cunha Domingos ${ }^{3}$, Dirceu Bartolomeu Greco ${ }^{5}$
}

\author{
'Laboratório Central, Hospital das Clínicas ²Departamento de Ginecologia e Obstetrícia ${ }^{3}$ Laboratório de Doenças Infecciosas e Parasitárias \\ ${ }^{4}$ Departamento de Anatomia Patológica e Medicina Legal ${ }^{5}$ Departamento de Clínica Médica, Faculdade de Medicina, \\ Universidade Federal de Minas Gerais, Belo Horizonte, MG, Brasil
}

Understanding the social conditions and immunological characteristics that allow some human immunodeficiency virus (HIV)-exposed patients to remain uninfected represents an on-going challenge. In this study, the sociodemographic and sexual behaviour characteristics and immune activation profiles of uninfected individuals exposed to HIV-infected partners were investigated. A confidential and detailed questionnaire was administered and venous blood was tested using HIV-1/enzyme immunoassays, plasma HIV-1 RNA levels/bDNA and immunophenotyping/flow cytometry to determine the frequencies of CD4 and CD8 T cells expressing activation markers. The data analysis showed significant differences $(p<0.05)$ for immune parameters in individuals who were uninfected, albeit exposed to HIV-infected partners, compared with unexposed individuals. In particular, the exposed, uninfected individuals had a higher frequency (median, minimum-maximum) of $C D 4^{+} H L A-D R^{+}$(4.2, 1.8-6.1), $C D 8^{+} H L A-D R^{+}$(4.6, 0.9-13.7), $C D 4^{+} C D 45 R O^{+}$(27.5, 14.2-46.6), $C D 4^{+} C D 45 R O^{+} C D 62 L^{+}$(46.7, 33.9-67.1), $C D 8^{+} C D 45 R A^{+} H L A-D R^{+}$(12.1, 3.4-35.8) and $C D 8^{+} C D 45 R O^{+} H L A-D R^{+}$(9.0, 3.2-14.8) cells, a decreased percentage of $C D 8^{+} C D 28^{+}$cells (11.7, 4.5-24.0) and a lower cell-surface expression of Fcy-R/CD16 on monocytes (56.5, 22.0-130.0). The plasma HIV-1 RNA levels demonstrated detectable RNA virus loads in $57 \%$ of the $H I V-1^{+}$female partners. These findings demonstrate an activation profile in both CD4 and CD8 peripheral T cells from HIV-1 exposed seronegative individuals of serodiscordant couples from a referral centre in Belo Horizonte, state of Minas Gerais.

Key words: HIV-1 discordant couples - flow cytometry - immune activation - immunophenotyping

Heterosexual intercourse is currently the main route of human immunodeficiency virus type 1 (HIV-1) acquisition worldwide and the rate of transmission in this manner is increasing throughout Africa, Asia, Latin America and many industrialised countries (Piot et al. 2001, Yang et al. 2005).

The risk of transmission has been associated with a wide variety of behaviours, such as the frequency and type of sexual contact (Quinn et al. 2000, Kaur \& Mehra 2009) and the use or non-use of condoms, as well as types of interindividual variability, including genetic predisposition, intrinsic cellular defence mechanisms and mucosal and systemic HIV-1-specific cellular and humoral responses (Soriano et al. 2002, Kaslow et al. 2005). These variations in immunity can also impact natural killer (NK) cell activity, HIV-specific immunoglobulin A levels and HIV-specific T cells (Mazzoli et al. 1997, Kaul et al. 2001a, Lo Caputo et al. 2003, Make-

doi: $10.1590 / 0074-0276140140$

Financial support: FAPEMIG

+ Corresponding author: mariasil@hc.ufmg.br

Received 24 April 2014

Accepted 7 July 2014 donas et al. 2005). In addition, virus characteristics and levels of plasma viral load (PVL) have been implicated in resistance to infection (Operskalski et al. 1997).

It has been reported that some individuals remain HIV seronegative despite being exposed to HIV, in some cases repeatedly and over long periods of time. These individuals are called HIV-exposed seronegatives (HESN). Although host factors are involved in the production of this resistance to HIV acquisition, there is no clear explanation for such a low susceptibility to infection (Rowland-Jones \& McMichael 1995, Restrepo et al. 2011). Immune activation has been suggested to be critical in the susceptibility to HIV-1 transmission. In vitro, HIV-1 requires activated T cells for a productive infection (Kaur \& Mehra 2009) and subjects with an activated immune system show increased in vitro susceptibility to HIV and higher in vivo replication (Lawn et al. 2001).

HIV-1 replicates preferentially in $\mathrm{CD}^{2} 5 \mathrm{RO}^{+}$memory $\mathrm{T}$ lymphocytes rather than immature and immunologically quiescent naïve CD45RA $\mathrm{R}^{+}$lymphocytes (Spina et al. 1997, Woods et al. 1997). Additionally, the upregulation of adhesion molecules during inflammatory processes may further promote virus-induced cell-cell fusion, thereby facilitating the direct spread of the virus between cells (Hildreth \& Orentas 1989, Lawn et al. 2001).

As highly active antiretroviral therapy has greatly improved the quality of life of HIV-positive patients, 
the number of discordant couples (in which the male is HIV positive and the female is negative or vice versa) who are interested in pregnancy is increasing (Vernazza et al. 2000).

A better understanding of the genetic and immunologic bases of natural resistance to HIV-1 infection could be important for the development of preventive and therapeutic modalities. In this study, we investigated the socio-demographics, sexual behaviour and immune activation and memory status of peripheral blood leukocytes from uninfected individuals exposed to HIV-1-infected partners and compared these results with the results of unexposed individuals using flow cytometry. The aim was to characterise immunophenotyping features that might facilitate an understanding of the immunological features of Brazilian HIV-1 serodiscordant couples.

\section{SUBJECTS, MATERIALS AND METHODS}

Study groups - Fourteen individuals who were uninfected yet exposed to HIV-infected partners (HESN) as part of a group of HIV-1 discordant heterosexual couples who visited the Clinics Hospital of Federal University of Minas Gerais (UFMG) were invited to participate in the study. The inclusion criteria were an HIV-seronegative male partner and an HIV-1 infected female partner, a stable relationship and a history of penetrative sexual intercourse without condom use within the six months prior to the study. Ten volunteer, HIV-1-negative males (10 low-risk laboratory personnel unexposed to HIV-infected partners) who reported no sexual intercourse with an HIV1-positive partner were recruited to form the negative, HVI-1-unexposed seronegative group (HUSN). All of the subjects were interviewed to ascertain their socio-demographic characteristics \{i.e., educational level, family income, religion and sexual behaviour [age at 1st intercourse, frequency of intercourse, practice of oral and/or anal sex during the previous 6 months, reported sexually transmitted diseases (STDs) and duration of relationship]\}.

Blood samples - Peripheral blood samples (5 and $7 \mathrm{~mL}$ ) were collected by a trained professional at the Central Laboratory of the Clinics Hospital and placed into Vacutainer ${ }^{\mathrm{TM}}$ tubes containing ethylenediamine tetraacetic acid (EDTA) as an anticoagulant, a clot activator and gel for serum separation (both purchased from Becton Dickinson, USA). Serologic tests for HIV-1 were used to detect anti-HIV antibodies using microparticle enzyme immunoassays (MEIA) for HIV-1 and HIV-2 (Abbott Laboratories, USA) and were performed at the Central Laboratory. Plasma HIV-1 RNA levels (VLs) were quantified using VERSANT HIV-1 RNA 3.0 Assay (bDNA) (Siemens Healthcare Diagnostics). A flow cytometric analysis of unstimulated whole blood was performed as recommended by Becton Dickinson with the following modifications. First, $50-\mu \mathrm{L}$ aliquots of EDTA-anticoagulated blood were dispensed into 5-mL polystyrene tubes (Falcon ${ }^{\circledR}$, BD Pharmingen, USA). The samples were then individually stained for specific cellsurface markers using three or four-colour immunocytometric assays with the following anti-human cell surface marker monoclonal antibodies conjugated to fluorescein isothiocyanate (FITC), phycoerythrin (PE), peridinin- chlorophyll protein (PerCP), R-PE or cyanine dye Cy5 (PE Cy5.0) and allophycocyanin (APC): anti-CD4 FITC (RPA-T4), anti-CD8 PerCP (RPA-T8), anti-CD3 FITC (UCHT1), anti-CD3 PerCP (SP34-2), anti-CD14 FITC (M5E2), anti-CD16 PE Cy5.0 (3G8), anti-CD18 PE (6.7), anti-CD28 PE (CD28.2), anti-CD38 PE (HIT2), antiCD45RA PE (HI100), anti-CD45RO PE (UCHL1), antiCD56 PE (B159), anti-CD62L APC (DREG-56), antiHLA-DR PE (G46-6), anti-HLA-DR APC (MøP9) and anti-CCR5 APC (2D7/CCR5). These antibodies were purchased from BD Pharmingen.

The samples were gently treated with vortex homogenisation and incubated in the dark for $30 \mathrm{~min}$ at room temperature (RT). Following incubation, the erythrocytes were lysed using $0.45 \mathrm{~mL}$ of fluorescence-activated cell sorter (FACS) lysing solution (Becton Dickinson) and re-incubated for an additional $15 \mathrm{~min}$ at RT in the dark. After incubation, the cells were washed twice with $2 \mathrm{~mL}$ of phosphate-buffered saline (PBS) containing $0.01 \%$ sodium azide (NaN3). After erythrocyte lysis was complete, the samples were centrifuged at $600 \mathrm{~g}$ for $7 \mathrm{~min}$ at RT. The supernatants were discarded and the cell pellets were washed twice with $2 \mathrm{~mL}$ of PBS containing $0.01 \% \mathrm{NaN} 3$ and stored at $4^{\circ} \mathrm{C}$ in the dark prior to flow cytometry analysis. FACS data were acquired within $4 \mathrm{~h}$ after staining.

Flow cytometry acquisition and analysis - In total, 3,000 events/tube were acquired within the lymphocyte gate using a FACSCalibur ${ }^{\circledR}$ flow cytometer (Becton Dickinson) that was properly set up to measure forward (FSC) and side (SSC) light scatters, FITC (FL-1), PE (FL-2), PerCP or PE Cy5.0 (FL-3) and APC (FL4). The CELLQuest $^{\mathrm{TM}}$ software (Franklin Lakes, USA), which was provided by the manufacturer, was used for the data acquisition and analysis and the data were prepared using the FlowJo software (Tree Star, USA). The selective analysis of lymphocytes was carried out by first placing an electronic gate on the FSC vs. SSC dot plot to select small blood lymphocytes based on their morphometric features. The gated lymphocyte population was further characterised based on its relative fluorescent properties to quantify the percentage of fluorescent-positive subpopulations. The selective analysis of NK and NKT cells was initially performed using the lymphocyte scatter gate, created according to the FSC vs. SSC dot plots, followed by immunophenotyping using anti-CD3 FITC, anti-CD16 PE Cy5.0 and anti-CD56 PE to determine the subpopulation of interest. The analysis of monocytes was performed by immunophenotyping using SSC vs. FL-1/anti-CD14-FITC dot plots to select SSC ${ }^{\text {Low }} \mathrm{CD} 14^{\text {High }}$ monocytes, followed by immunophenotyping using anti-CD16 PE Cy5 and HLA-DR PE. The results were expressed as the percentage of positive cells within the selected gates. Cell-surface markers presenting a bimodal distribution and/or single-colour histograms were used to evaluate the density or expression of cell-surface markers presenting a unimodal distribution, which was expressed as the mean fluorescence intensity, within the gated lymphocytes or monocytes.

Statistical analysis - The statistical analysis was performed using the non-parametric Mann-Whitney $U$ test to compare the mean rates obtained from the HESN and 
HUSN groups using GraphPad Prism software, v.5.0 (USA). Significant differences were considered at $\mathrm{p} \leq 0.05$.

Ethics - All of the subjects signed an informed consent form that was approved by the Ethical Committee of UFMG (UFMG-ETIC 261/2009), Belo Horizonte, state of Minas Gerais, Brazil.

\section{RESULTS}

The socio-demographic and sexual behaviour characteristics of the individuals enrolled in this study are shown in Table I. The age range of the HESN and HUSN individuals varied from 28-56 and 20-38 years, respectively. The median age for first reported sexual intercourse was 10-15 years among the HESN group and 14-18 years among the HUSN group. Among the HESN individuals, the median duration of cohabitation was 8.5 years (range from 5-10 years) and the median number of sexual acts per week was three times; oral and anal sex in the past six months were reported by $57.1 \%$ and $28.6 \%$ of the subjects, respectively. Among the HESN subjects, $14.3 \%$ reported a previous history of any STD and a minority $(42.9 \%)$ reported regular condom use. For the HUSN group, the median duration of cohabitation was seven years and the median number of sexual acts per week was three. Oral sex in the past six months was reported by $40 \%$ individuals and all of the subjects denied practicing anal sex. Of the HUSN subjects, 50\% reported a previous history of an STD and a majority $(55.6 \%)$ reported the regular use of condoms. The majority of HESN subjects reported practicing a religion (92.9\%). In contrast, half of the HUSN group said they did not practice any religion. With regard to education, at least $64 \%$ of the individuals from the HESN group reported seven years of school; the majority $(100 \%)$ of the individuals in the HUSN group reported completing high school or beyond. Concerning income, $57.1 \%$ of the HESN group declared a family monthly income of less than US\$ 800 , whereas the majority (60\%) of the HUSN group reported a family income above US\$ 800 .

Regarding laboratory characteristics, all of the HESN and HUNS individuals were HIV-1 seronegative (as tested by MEIA). The plasma HIV-1 RNA levels (VL) demonstrated detectable RNA virus loads (detection threshold 50 copies $/ \mathrm{mL}$ ) in eight out of $14(57 \%)$ of the HIV-1 ${ }^{+}$ female partners. The median of RNA virus loads in copies/mL and minimum-maximum (min-max) was 4,691 and 228-26,302 and in $\log _{10}$ and min-max was 3,269 and 2,358-4,420 (Table II). CD4 counts were determined for all of the subjects and the median CD4 counts observed in the HESN and HUSN groups were $931(529-2,000)$ and $760(573-1,326)$ cells $/ \mu \mathrm{L}$, respectively (Table II). No differences were observed when the HESN and HUNS data were compared.

An ex vivo analysis of leukocyte subsets (frequency, activation status and $\mathrm{C}-\mathrm{C}$ chemokine receptor type 5 expression) present in the peripheral blood was performed using four-colour flow cytometry assays (Figs 1-3). The results of the HESN group were compared to the results of the HUSN group.

No statistically significant difference was observed when comparing the $\mathrm{CCR} 5^{+} \mathrm{CD} 4^{+}$and $\mathrm{CCR} 5^{+} \mathrm{CD} 8^{+}$results between the HESN and HUSN individuals (Fig. 1D). The frequency of CCR5 expression in peripheral T cells from the HESN group was 12 (4.9-17.6) for CD4 ${ }^{+}$ cells and 14.7 (6.7-32.5) for CD8 $8^{+}$cells. In the HUSN group, the frequencies of $\mathrm{CD} 4^{+} \mathrm{CCR} 5^{+}$and $\mathrm{CD} 8^{+} \mathrm{CCR}^{+}$ T cells were 10.9 (2.6-16.3) and 12.9 (2.8-19.9), respectively. When the activation status of peripheral $\mathrm{T}$ cells was examined, the activation profile of $\mathrm{T}$ cells among the HESN group compared with the HUSN group was characterised by a lower frequency of $\mathrm{CD} 8^{+} \mathrm{CD} 28^{+}$cells and a higher frequency of $\mathrm{CD} 4^{+} \mathrm{HLA}-\mathrm{DR}^{+}$and $\mathrm{CD} 8^{+} \mathrm{HLA}-$ $\mathrm{DR}^{+} \mathrm{T}$ cells (Fig. 1A, B). An analysis of adhesion molecule expression among circulating $\mathrm{T}$ cells showed no

\section{TABLE I}

Socio-demographic and sexual behaviour characteristics of 14 human immunodeficiency virus type 1 (HIV-1) exposed seronegative (HESN) and 10 unexposed seronegative (HUSN) heterosexual men

\begin{tabular}{lcc}
\hline Characteristics & HESN & HUSN \\
\hline Age (years) (mean) & 39.1 & 26.6 \\
Age at first sex (years) (mean) & 15.5 & 18 \\
Average of sexual acts/week & 3.0 & 3.0 \\
Reported oral sex in the past six months (\%) & 57.1 & 40 \\
Reported anal intercourse in the past six months (\%) & 28.6 & 0 \\
Self reported sexually transmitted disease (\%) & 14.3 & 50 \\
Self reported regular condom use (\%) & 42.9 & 55.6 \\
Duration of union (years) (mean) & 8.5 & 7 \\
Number of children (mean) & 1 & $<1$ \\
Religiousness (\%) & 92.8 & 50 \\
Catholic (\%) & 35.7 & 30 \\
Protestant (\%) & 57.1 & 10 \\
Education (years) (mean) & 6.4 & 12.6 \\
Income (< US\$800/month) (\%) & 57.1 & 40 \\
\hline
\end{tabular}


TABLE II

Laboratory characterisation of 14 exposed seronegative heterosexual men and their partners

\begin{tabular}{|c|c|c|c|c|c|c|}
\hline \multicolumn{3}{|c|}{ Exposed seronegative men } & \multicolumn{4}{|c|}{ Human immunodeficiency virus type 1 (HIV-1)-infected women } \\
\hline ID & $\begin{array}{c}\text { CD4 } \\
\text { (cells } / \mu \mathrm{L})\end{array}$ & $\begin{array}{c}\text { CD8 } \\
\text { (cells } / \mu \mathrm{L})\end{array}$ & ID & $\begin{array}{l}\text { HIV-1 RNA } \\
\text { (copies/mL) }\end{array}$ & $\begin{array}{c}\text { CD4 } \\
\text { (cells } / \mu \mathrm{L})\end{array}$ & $\begin{array}{c}\text { CD8 } \\
(\text { cells } / \mu \mathrm{L})\end{array}$ \\
\hline M-001 & 1,160 & 209 & F-001 & 746 & 389 & 468 \\
\hline M-002 & 600 & 378 & F-002 & 5,975 & 550 & 1,162 \\
\hline M-003 & 931 & 537 & F-003 & $<50$ & 259 & 433 \\
\hline M-004 & 685 & 465 & F-004 & 883 & 299 & 1,227 \\
\hline M-005 & 769 & 356 & F-005 & 10,111 & 449 & 2,617 \\
\hline M-006 & 969 & 916 & F-006 & $<50$ & 877 & 1,182 \\
\hline M-007 & 804 & 2,117 & F-007 & 26,302 & 374 & 983 \\
\hline M-008 & 1,147 & 626 & F-008 & 12,456 & 338 & 309 \\
\hline M-010 & 1,634 & 778 & F-010 & $<50$ & 651 & 756 \\
\hline M-011 & 954 & 813 & F-011 & 3,407 & 439 & 854 \\
\hline M-012 & 2,000 & 553 & F-012 & 228 & 1,317 & 705 \\
\hline M-013 & 742 & 672 & F-013 & $<50$ & 977 & 590 \\
\hline M-014 & 529 & 487 & F-014 & $<50$ & 499 & 832 \\
\hline M-015 & 1,096 & 555 & F-015 & $<50$ & 1,228 & 1,287 \\
\hline
\end{tabular}

data are expressed as cells/ $\mu \mathrm{L}$ for CD4 and CD8 T cells and copies/mL for HIV-1 RNA levels. F: females; M: males.

significant differences in CD18 expression on CD4 and CD8 $\mathrm{T}$ cells (Fig. 1E) or in the frequency of $\mathrm{CD}^{+}$and $\mathrm{CD}^{+} \mathrm{CD}^{2} \mathrm{~L}^{+}$cells (Fig. 1F).

To evaluate the patterns and activation status of naïve and memory $\mathrm{T}$ cells in peripheral blood, the frequency of CD45RA, CD45RO, CD62L and HLA-DR expression was investigated using multicolour flow cytometric assays (Fig. 2). The analysis of the data demonstrated an increased frequency of naïve, activated CD8 $\mathrm{T}$ cells $\left(\mathrm{CD}^{+} \mathrm{CD}^{4} \mathrm{RA}^{+} \mathrm{HLA}^{\left.-\mathrm{DR}^{+}\right)}\right.$in the HESN group (Fig. 2C), though no difference was found in the frequency of $\mathrm{CD}^{2} 2 \mathrm{~L}^{+} \mathrm{CD} 45 \mathrm{RA}^{+}$cells among CD4 and CD8 $\mathrm{T}$ cells (Fig. 2B). In addition, higher levels of memory cells were demonstrated in the HESN individuals, which were characterised by increased levels of $\mathrm{CD}^{+} \mathrm{CD}^{4} 5 \mathrm{RO}^{+}$cells (Fig. 2D), central memory cells $\left(\mathrm{CD}^{+} \mathrm{CD}^{4}\right.$ RO $\mathrm{RO}^{+} \mathrm{CD}^{+} \mathrm{L}^{+}$) (Fig. 2E) and memory-activated cells $\left(\mathrm{CD}^{+}\right.$and $\left.\mathrm{CD}^{+} \mathrm{CD} 45 \mathrm{RO}^{+} \mathrm{HLA}^{-} \mathrm{DR}^{+}\right)$(Fig. $\left.2 \mathrm{G}\right)$. No significant difference was observed between the groups in terms of the percentage of effector memory $\mathrm{T}$ cells (CD4 and $\mathrm{CD}^{+} \mathrm{CD}^{2} \mathrm{RO}^{+} \mathrm{CD}^{2} 2 \mathrm{~L}^{-}$) (Fig. 2F).

The monocyte expression of HLA-DR, CD16 and CCR 5 and the frequency of circulating NK (CD3- ${ }^{-}$D16 ${ }^{+/-}$ $\left.\mathrm{CD}^{+/-}\right)$and $\mathrm{NKT}\left(\mathrm{CD}^{+} \mathrm{CD}^{+/-} 6^{+-} \mathrm{CD} 56^{+/}\right)$cells was also analysed (Fig. 3). However, no significant differences were observed in the expression of HLA-DR or CCR5 by monocytes (Fig. 3A, B) or in the frequency of circulating NK and NKT cells between the groups (Fig. 3C). In contrast, decreased cell-surface expression of Fc $\gamma-\mathrm{R}$ (CD16) was observed on the monocytes obtained from the HESN group (Fig. 3A).

\section{DISCUSSION}

Few studies characterising HIV-1-discordant couples have been conducted in our country and only a small

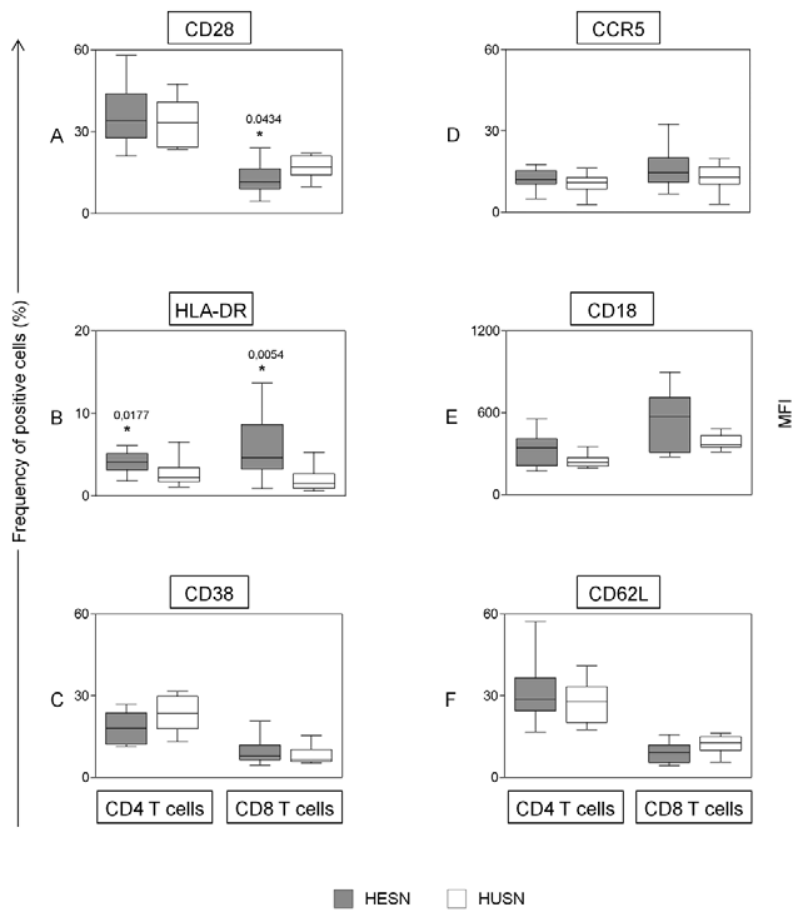

Fig. 1: frequency of $\mathrm{T}$ cell activation and adhesion molecule expression in the whole blood samples of the human immunodeficiency virus type $1(\mathrm{HIV}-1)$-exposed seronegatives $(\mathrm{HESN})(\mathrm{n}=14)$ or HVI1 -unexposed seronegative group (HUSN) individuals $(n=10)$. The results are expressed in a box plot format for the frequency of CD28, CD38, CD62L, HLA-DR, CCR5 and the mean fluorescence intensity (MFI) of CD18 in CD4 and CD8 T cells. The box stretches from the lower hinge (defined as the 25 th percentile) to the upper hinge (the 75 th percentile) and, therefore, contains the middle half of the score in the distribution. The median is shown as a line across the box. Therefore, $1 / 4$ of the distribution is between this line and the bottom or the top. Significant differences $(\mathrm{p}<0.05)$ are indicated with an asterisk. 

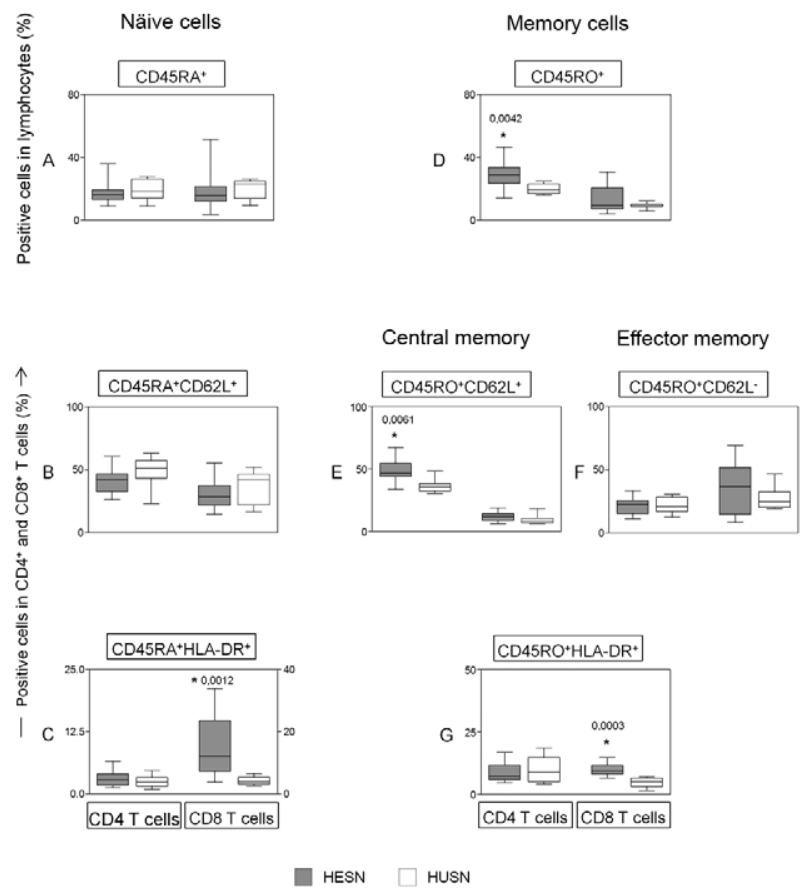

Fig. 2: status of naïve and memory T cells in the unstimulated peripheral blood of the human immunodeficiency virus type 1 (HIV-1)-exposed seronegatives $(\mathrm{HESN})(\mathrm{n}=14)$ or HVI-1-unexposed seronegative group $($ HUSN) $(n=10)$ groups. The results are expressed in a box plot format for the frequency of naïve $\mathrm{T}$ cells $\left(\mathrm{CD} 45 \mathrm{RA}^{+}\right.$or $\left.\mathrm{CD} 45 \mathrm{RA} \mathrm{A}^{+} \mathrm{CD} 62 \mathrm{~L}^{+}\right)$ (left panels), memory $\mathrm{T}$ cells $\left(\mathrm{CD}^{2} 5 \mathrm{RO}^{+}\right)$(right panels), which are classified as central memory $\mathrm{T}$ cells $\left(\mathrm{CD} 45 \mathrm{RO}^{+} \mathrm{CD} 62 \mathrm{~L}^{+}\right)$and effector memory $\mathrm{T}$ cells $\left(\mathrm{CD} 45 \mathrm{RO}^{+}, \mathrm{CD} 62 \mathrm{~L}^{-}\right)$(left panels) and naïve or memory-activated $\left(\mathrm{CD} 45 \mathrm{RA}^{+} / \mathrm{CD} 45 \mathrm{RO}^{+}\right.$HLA-DR ${ }^{+}$) T cells (left and right bottom panels). The box stretches from the lower hinge (defined as the 25th percentile) to the upper hinge (the 75th percentile) and therefore, contains the middle half of the scores in the distribution. The median is shown as a line across the box. Therefore $1 / 4$ of the distribution is between this line and the bottom or the top of the box. Significant differences $(p<0.05)$ are identified with an asterisk.

number of them have been performed as an immunological investigation. Aiming to characterise the sociodemographic determinants, sexual behaviours and immunophenotypic patterns of uninfected individuals exposed to HIV-1-infected partners, this study enrolled 14 heterosexual men from HIV-1-serodiscordant couples who were assisted in a large referral centre in Belo Horizonte, as well as 10 individuals not exposed to HIV-1infected partners.

The demographic and behavioural characteristics observed in this study reflect the current state of the HIV/acquired immune deficiency syndrome epidemic in Brazil, especially with regard to pauperisation (Brito et al. 2001). Individuals who were uninfected, but exposed to HIV-infected partners from HIV-1-discordant heterosexual couples demonstrated greater indicators of poverty, such as a poor education and insufficient income and, consequently, reported a low adherence to condom use and a large number of children. These characteristics are similar to those reported in other studies performed in Africa and China in HIV-1-serodiscordant couples (Isiugo-Abanihe 2006, Matovu 2010, Duan et al. 2012).
Another intriguing result was the great religious bond of exposed, uninfected partners, mainly those of Protestant religions. Hypothetically, this link to religious practices could influence sexual behaviour and promote safe sex (Muñoz-Laboy et al. 2011); however, our results showed the opposite trend for uninfected partners, as sexual practices with a high risk for HIV transmission remained despite the declaration of religious practice. Unfortunately, we did not ask how long the individuals were practicing their religious precepts or whether they ascribed to them after learning the HIV status of their partner.

The transmission and acquisition of HIV-1 have been associated with VL as well as viral and host biological characteristics (Operskalski et al. 1997, Quinn et al. 2000, Kaslow et al. 2005). Gray et al. (2001), in an observational study of monogamous, HIV-1-serodiscordant couples, identified plasma HIV-1 RNA as the strongest predictor of HIV-1 transmission, with transmission probabilities that increased with genital ulceration (Gray et al. 2001). Our data demonstrated a detectable RNA virus load in $57 \%$ of the infected female partners; however, the VL was low $(<10,000$ copies $/ \mathrm{mL})$ in these women. Furthermore, $87.7 \%$ of the HESN group reported no history of any STD. These data together might have contributed to the HIV-1 seronegative status in this study. Although VL
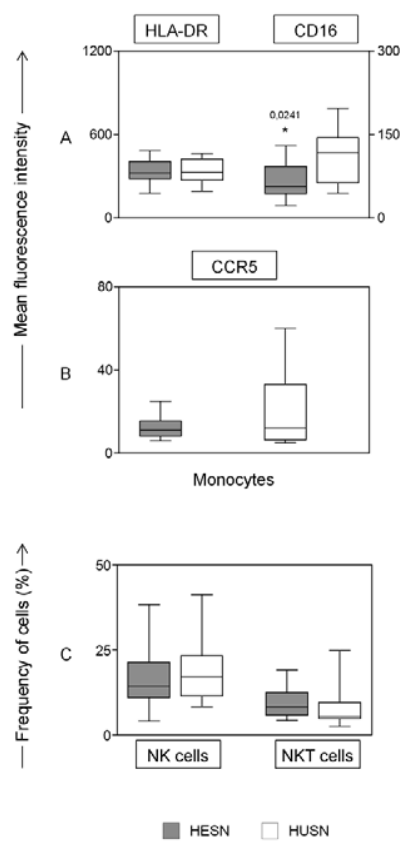

Fig. 3: analysis of monocytes, natural killer (NK) and NKT lymphocyte subsets in the whole blood of the human immunodeficiency virus type $1(\mathrm{HIV}-1)$-exposed seronegatives $(\mathrm{HESN})(\mathrm{n}=14)$ or HVI1-unexposed seronegative group (HUSN) $(n=10)$ groups. A triple staining immunophenotyping platform was used to identify the lymphocyte subsets as $\mathrm{CD} 3-\mathrm{CD} 16^{+} \mathrm{CD} 56^{+} \mathrm{NK}$-cells or $\mathrm{CD}^{+} \mathrm{CD} 16^{+} \mathrm{CD} 56^{+}$ NKT-cells. The results are expressed in a box plot format. The box stretches from the lower hinge (defined as the 25 th percentile) to the upper hinge (the 75th percentile) and therefore, contains the middle half of the scores in the distribution. The median is shown as a line across the box. Therefore, $1 / 4$ of the distribution is between this line and the bottom or the top of the box. Significant differences $(p<0.05)$ are identified with an asterisk. 
has been associated with an increased rate of seroconversion, the same trend was not demonstrated for CD4 cell levels (Pedraza et al. 1999, Fideli et al. 2001, Melo et al. 2008). In our study, there were no significant differences in CD4 counts; however, immune changes characterised by an activation pattern of CD4 and CD8 T cells in the peripheral blood of the HESN individuals were observed. CD8-activated lymphocytes in the peripheral circulation play an important role in the host antiviral response (Lawn et al. 2001). It was also reported that cytotoxic T lymphocytes play a role in resistance to HIV infection, though this resistance is believed to be dependent on the persistent exposure to HIV (Kaul et al. 2001b).

Two hypotheses have been suggested to explain the immunophenotypic changes observed in the HESN group. The immunophenotypic changes observed in highly HIV-exposed, uninfected individuals could be a consequence of immunogenic challenge during viral exposure. Mucosal and systemic immune activation was reported in seronegative women who had multiple episodes of unprotected heterosexual intercourse with their HIV-1-infected heterosexual partners, as demonstrated by lower levels of naïve $\mathrm{CD} 4^{+} \mathrm{T}$ cells and a higher level of $\mathrm{CD}^{+}$memory, $\mathrm{CD} 4^{+} \mathrm{CD} 28, \mathrm{CD}^{+} \mathrm{CD} 28^{+}$and $\mathrm{CD} 8^{+} \mathrm{CD} 38^{+} \mathrm{T}$ cells than in healthy control subjects (Biasin et al. 2000). Suy et al. (2007) observed changes in the memory and activated T cells of highly HIV-exposed, uninfected partners, including lower levels of naïve and $\mathrm{CD} 28^{+} \mathrm{T}$ cells and higher levels of HLA-DR ${ }^{+} \mathrm{T}$ cells, $\mathrm{CD}^{+} \mathrm{T}$ cells expressing CCR5 and memory $\mathrm{CD} 4^{+} \mathrm{T}$ cells, compared with control subjects. Because immune activation has been suggested to be critical for HIV-1 transmission susceptibility (Pedraza et al. 1999, Camara et al. 2010), it is reasonable to hypothesise that the individuals with lower levels of immune activation would have a decreased susceptibility to HIV infection. Within this context, some investigators have found low levels of $\mathrm{CD}^{+} \mathrm{T}$ cell immune activation and low $\mathrm{T}$ cell responsiveness in studies involving HESN individuals. In a cohort of highly exposed, but HIV-seronegative men who had sex with men in Amsterdam, higher naïve (CD45RO$\left.\mathrm{CD} 27^{+}\right) \mathrm{CD} 4$ and CD8 T cell numbers and lower percentages of activated (HLADR $\left.{ }^{+} \mathrm{CD} 38^{+}, \mathrm{CD} 70^{+}\right) \mathrm{CD} 4$ and proliferating (Ki67) CD4 and CD8 T cells were observed (Koning et al. 2005). Bégaud et al. (2006) also reported a lower proportion of activation marker-expressing $\mathrm{CD} 4 \mathrm{~T}$ lymphocytes (HLA-DR ${ }^{+} \mathrm{CD} 4$ and $\mathrm{CCR} 5^{+} \mathrm{CD} 4 \mathrm{~T}$ cells) in highly exposed, uninfected partners of HIV-1-infected individuals compared to low-risk controls.

Our data revealed an increased activation pattern in naïve and memory $\mathrm{CD} 4^{+}$and $\mathrm{CD} 8^{+} \mathrm{T}$ cells, as well as an increased frequency of memory cells, in HESN individuals compared with HUSN individuals. We also found a low VL in 57\% of the female partners of the HESN group, corroborating the first hypothesis. However, our data did not demonstrate a significant difference in CCR 5 expression on $\mathrm{CD}^{+} \mathrm{T}$ cells, as previously described (Biasin et al. 2000, Koning et al. 2005, Bégaud et al. 2006). Decreased monocyte CD16 expression in the HESN group was observed in our work; Fc $\gamma$ RIII (CD16) is normally associated with the activation or maturation of monocytes and circulating $\mathrm{CD} 14^{+} \mathrm{CD} 16^{+}$monocytes are an important cellular target for HIV-1 entry (Han et al. 2009).
Susceptibility to HIV infection varies among individuals; however, the mechanisms determining HIV transmission are not well understood. Thus, the multiple virological, immunological and host factors that are likely involved in protecting against HIV-1 infection should be more extensively investigated.

Our findings demonstrate immunological features (i.e., a higher frequency of activation markers on CD4 and CD8 naïve and memory T cells) in this study of uninfected Brazilians exposed to HIV-infected partners. The data presented in this paper represent the preliminary results of a pilot study involving a small number of individuals and further investigations are required to obtain a better understanding of these immunological differences.

\section{REFERENCES}

Bégaud E, Chartier L, Marechal V, Ipero J, Léal J, Versmisse P, Breton G, Fontanet A, Capoulade-Metay C, Fleury H, Barré-Sinoussi F, Scott-Algara D, Pancino G 2006. Reduced CD4 T cell activation and in vitro susceptibility to HIV-1 infection in exposed uninfected central Africans. Retrovirology 3: 35 .

Biasin M, Caputo SL, Speciale L, Colombo F, Racioppi L, Zagliani A, Blé C, Vichi F, Cianferoni L, Masci AM, Villa ML, Ferrante P, Mazzotta F, Clerici M 2000. Mucosal and systemic immune activation is present in human immunodeficiency virus-exposed seronegative women. J Infect Dis 182: 1365-1374.

Brito AM, Castilho EA, Szwarcwald CL 2001. AIDS and HIV infection in Brazil: a multifaceted epidemic. Rev Soc Bras Med Trop 34: 207-217.

Camara M, Dieye TN, Seydi M, Diallo AA, Fall M, Diaw PA, Sow PS, Mboup S, Kestens L, Jennes W 2010. Low-level CD4+ T cell activation in HIV-exposed seronegative subjects: influence of gender and condom use. J Infect Dis 201: 835-842.

Duan S, Ding Y, Yang Y, Lu L, Sun J, Wang N, Wang L, Xiang L, Jia M, Wu Z, He N 2012. Prevalence and correlates of HIV discordance and concordance among Chinese-Burmese mixed couples in the Dehong prefecture of Yunnan province, China. Sex Health 9: 481-487.

Fideli US, Allen SA, Musonda R, Trask S, Hahn BH, Weiss H, Mulenga J, Kasolo F, Vermund SH, Aldrovandi GM 2001. Virologic and immunologic determinants of heterosexual transmission of human immunodeficiency virus type 1 in Africa. AIDS Res Hum Retroviruses 17: 901-910.

Gray RH, Wawer MJ, Brookmeyer R, Sewankambo NK, Serwadda D, Wabwire-Mangen F, Lutalo T, Li X, van Cott T, Quinn TC, Rakai Project Team 2001. Probability of HIV-1 transmission per coital act in monogamous, heterosexual, HIV-1-discordant couples in Rakai, Uganda. Lancet 357: 1149-1153.

Han J, Wang B, Han N, Zhao Y, Song C, Feng X, Mao Y, Zhang F, Zhao H, Zeng H 2009. CD14 ${ }^{\text {high }} \mathrm{CD} 16^{+}$rather than $\mathrm{CD} 14^{\text {low }} \mathrm{CD} 16^{+}$ monocytes correlate with disease progression in chronic HIVinfected patients. J Acquir Immune Defic Syndr 52: 553-559.

Hildreth JE, Orentas RJ 1989. Involvement of a leukocyte adhesion receptor (LFA-1) in HIV-induced syncytium formation. Science 244: $1075-1078$.

Isiugo-Abanihe UC 2006. Sociocultural aspects of HIV/AIDS infection in Nigeria. Afr J Med Med Sci 35 (Suppl.): S45-S55.

Kaslow RA, Dorak T, Tang JJ 2005. Influence of host genetic variation on susceptibility to HIV type 1 infection. J Infect Dis 191 (Suppl. 1): S68-S77.

Kaul R, Plummer F, Clerici M, Bomsel M, Lopalco L, Broliden K 2001a. Mucosal IgA in exposed, uninfected subjects: evidence for a role in protection against HIV infection. AIDS 5: 431-432. 
Kaul R, Rowland-Jones SL, Kimani J, Dong T, Yang HB, Kiama P, Rostron T, Njagi E, Bwayo JJ, MacDonald KS, McMichael AJ, Plummer FA 2001b. Late seroconversion in HIV-resistant Nairobi prostitutes despite pre-existing HIV-specific $\mathrm{CD} 8^{+}$responses. J Clin Invest 107: 341-349.

Kaur G, Mehra N 2009. Genetic determinants of HIV-1 infection and progression to AIDS: susceptibility to HIV infection. Tissue Antigens 73: 289-301.

Koning FA, Otto SA, Hazenberg MD, Dekker L, Prins M, Miedema F, Schuitemaker H 2005. Low-level CD4 ${ }^{+} \mathrm{T}$ cell activation is associated with low susceptibility to HIV-1 infection. J Immunol 175: 6117-6122.

Lawn SD, Butera ST, Folks TM 2001. Contribution of immune activation to the pathogenesis and transmission of human immunodeficiency virus type 1 infection. Clin Microbiol Rev 14: 753-777.

Lo Caputo S, Trabattoni D, Vichi F, Piconi S, Lopalco L, Villa ML, Mazzotta F, Clerici M 2003. Mucosal and systemic HIV-1-specific immunity in HIV-1-exposed, but uninfected heterosexual men. AIDS 17: 531-539.

Makedonas G, Bruneau J, Alary M, Tsoukas CM, Lowndes CM, Lamothe F, Bernard NF 2005. Comparison of HIV-specific CD8 T-cell responses among uninfected individuals exposed to HIV parenterally and mucosally. AIDS 19: 251-259.

Matovu JK 2010. Preventing HIV transmission in married and cohabiting HIV-discordant couples in sub-Saharan Africa through combination prevention. Curr HIV Res 8: 430-440.

Mazzoli S, Trabattoni D, Lo Caputo S, Piconi S, Blé C, Meacci F, Ruzzante S, Salvi A, Semplici F, Longhi R, Fusi ML, Tofani N, Biasin M, Villa ML, Mazzotta F, Clerici M 1997. HIV-specific mucosal and cellular immunity in HIV-seronegative partners of HIV-seropositive individuals. Nat Med 3: 1250-1257.

Melo MG, Santos BR, Lira RC, Varella IS, Turella ML, Rocha TM, Nielsen-Saines K 2008. Sexual transmission of HIV-1 among serodiscordant couples in Porto Alegre, southern Brazil. Sex Transm Dis 35: 912-915.

Muñoz-Laboy MA, Murray L, Wittlin N, Garcia J, Terto Jr V, Parker RG 2011. Beyond faith-based organizations: using comparative institutional ethnography to understand religious responses to HIV and AIDS in Brazil. Am J Public Health 101: 972-978.

Operskalski EA, Stram DO, Busch MP, Huang W, Harris M, Dietrich SL, Schiff ER, Donegan E, Mosley JW 1997. Role of viral load in heterosexual transmission of human immunodeficiency virus type 1 by blood transfusion recipients. Transfusion Safety Study Group. Am J Epidemiol 146: 655-661.
Pedraza MA, del Romero J, Roldán F, García S, Ayerbe MC, Noriega AR, Alcamí J 1999. Heterosexual transmission of HIV-1 is associated with high plasma viral load levels and a positive viral isolation in the infected partner. J Acquir Immune Defic Syndr 21: 120-125.

Piot P, Bartos M, Ghys PD, Walker N, Schwartländer B 2001. The global impact of HIV/AIDS. Nature 410: 968-973.

Quinn TC, Wawer MJ, Sewankambo N, Serwadda D, Li C, WabwireMangen F, Meehan MO, Lutalo T, Gray RH 2000. Viral load and heterosexual transmission of human immunodeficiency virus type 1. Rakai Project Study Group. N Engl J Med 342: 921-929.

Restrepo C, Rallón NI, Carrillo J, Soriano V, Blanco J, Benito JM 2011. Host factors involved in low susceptibility to HIV infection. AIDS Rev 13: 30-40.

Rowland-Jones SL, McMichael A 1995. Immune responses in HIVexposed seronegatives: have they repelled the virus? Curr Opin Immunol 7: 448-455.

Soriano A, Martínez C, García F, Plana M, Palou E, Lejeune M, Aróstegui JI, De Lazzari E, Rodriguez C, Barrasa A, Lorenzo JI, Alcamí J, del Romero J, Miró JM, Gatell JM, Gallart T 2002. Plasma stromal cell-derived factor (SDF)-1 levels, SDF1-3'A genotype and expression of CXCR4 on T lymphocytes: their impact on resistance to human immunodeficiency virus type 1 infection and its progression. J Infect Dis 186: 922-931.

Spina CA, Prince HE, Richman DD 1997. Preferential replication of HIV-1 in the CD45RO memory cell subset of primary CD4 lymphocytes in vitro. $J$ Clin Invest 99: 1774-1785.

Suy A, Castro P, Nomdedeu M, García F, López A, Fumero E, Gallart T, Lopalco L, Coll O, Gatell JM, Plana M 2007. Immunological profile of heterosexual highly HIV-exposed uninfected individuals: predominant role of CD4 and CD8 T-cell activation. $J$ Infect Dis 196: 1191-1201.

Vernazza PL, Troiani L, Flepp MJ, Cone RW, Schock J, Roth F, Boggian K, Cohen MS, Fiscus SA, Eron JJ 2000. Potent antiretroviral treatment of HIV-infection results in suppression of the seminal shedding of HIV. The Swiss HIV Cohort Study. AIDS 14: 117-121.

Woods TC, Roberts BD, Butera ST, Folks TM 1997. Loss of inducible virus in CD45RA naïve cells after human immunodeficiency virus-1 entry accounts for preferential viral replication in CD45RO memory cells. Blood 89: 1635-1641.

Yang H, Li X, Stanton B, Liu H, Liu H, Wang N, Fang X, Lin D, Chen X 2005. Heterosexual transmission of HIV in China: a systematic review of behavioral studies in the past two decades. Sex Transm Dis 32: 270-280. 